SHORT COMMUNICATION

\title{
Momordica dioica Roxb (Spine Gourd)- An underutilized vegetable and medicinal plant in Sri Lanka
}

\author{
M.G.W.K. Weerasinghe and N. Dahanayake*. \\ Department of Agriculture Biology, Faculty of Agriculture, University of Ruhuna, Sri Lanka \\ *Email: daha_27@yahoo.com \\ Received: 08.02.2021 ; Revised: 14.05.2021; Accepted : 20.05.2021
}

\begin{abstract}
Momordica dioica Roxb belongs to the family Cucurbitaceaeis a wild, perennial and creeping plant growing in the tropical and subtropical countries; Pakistan, China, India, Nepal and Sri Lanka. It is well known as folk medicine and nutritious vegetable as it contains various nutrients and phyto-chemicals with huge medicinal value. Different plant parts of $M$. dioica provide a number of phyto-constituents; alkaloids, steroids, triterpenoids, flavonoids, glycosides, ursolic acid, vitamins, minerals and rich in fibre. They are potential to cure asthma, excessive salivation and inflammation caused by lizards, snake bite, elephantiasis, fever, mental and digestive disorders and maintain skin health. According to the indigenous knowledge spine gourd plays a vital role in reducing various disorders like urinary disorders, digestive disease and as a remedy for bleeding. At the present scenario, $M$. dioica is considered as an underutilized, non-neglected plant in Sri Lanka. Extensive identification of M. dioica and its phyto-constituents provide huge potential to protect the plant biodiversity and enhance medicinal utilization. The paper highlighted the nutrient content, different uses, botany and cultivation aspects of $M$. dioica which will be helpful for the students and the interested peoples.
\end{abstract}

Keywords: Green medicine, Momordica dioica, phyto-constituents, spine gourd, underutilized vegetables.

\section{INTRODUCTION}

Use of synthetic drugs create the global health hazard and enhances the possibility of cancer, diabetes, neurodegenerative disorders. As a remedy for that, there is an urgent need for production of medicines using the natural herbs. Indigenous medicinal provide the favourable solution for the global healthhazard by reducing the negative impact of the synthetic drugs (Jha et al., 2017). Momordica dioica is a plant that considered as folk medicinal and nutrient rich vegetable. It contains a number specific constitution, called as phytoconstituents (alkaloids, tannins, fixed oil, flavonoids, sterol and amino acids) (Anjana et al., 2020). In Sri Lanka,it is a kind of underutilized vegetable but, according to the Thiruvengadam et al. (2011) there is a high demand in East India. It is considered a higher protein containing fruit in the Cucurbitaceous family (Bharathi et al., 2010). Spine gourds are very famous because of native bitter taste, due to the presence of phytochemicals like Triterpenes Momordicin, Lectins, Â-Sitosterol, Saponin, Glycosides are few of these alkaloid compound cause for its native bitterness (Jha et al., 2017).

IJMFM\&AP, Vol. 7 No. 2, 2021
Many researchers pay attention to developed new Momordica dioica varieties by up gradating the existing poor qualities. Indira Kantola I (RMF 37 ) is a new commercial variety developed by the Indira Gandhi Agricultural University in India. It was resistant to the major pest and can have harvest within 35- 40 days after the cultivation (Anjana et al., 2020). In the present situation underutilized useful plants like Momordica dioica face the extinction challenge (Dahanayake, 2015). Therefore; there should be proper conservation measures and awareness programme about nutritional and medicinal value of these plants.

\section{BOTANICAL DESCRIPTION}

Momordica dioica is a kind of vine, flowers are born during June to July and fruiting period from November to September. Male and female flowers are borne separately, so called as monosexual (Hitinayake et al., 2017). According to the literatures, around $22 \%$ of possibility to fruit set under the normal environment conditions and $100 \%$ possibility under the hand pollination conditions (Sandilya et al., 2019). Every node produces male and female floral buds. Male buds are produced during the second week of the August and continue to the first week of October. Female flowers are 


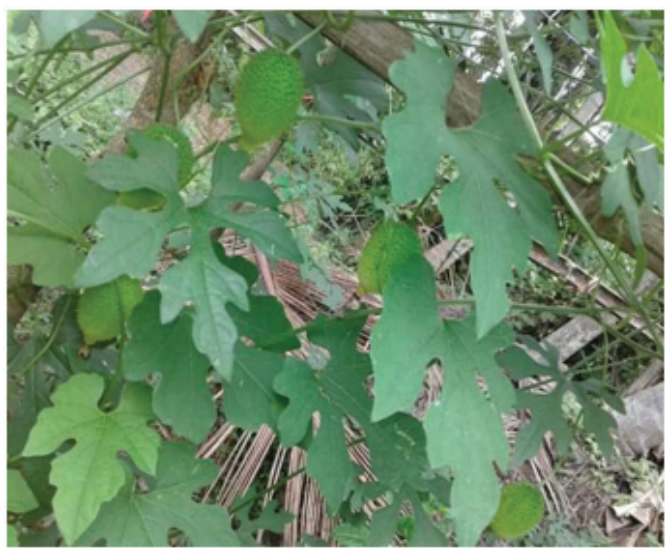

Fig. 1:Morphology of $M$. dioica leaf (simple leaf with deep lobes)

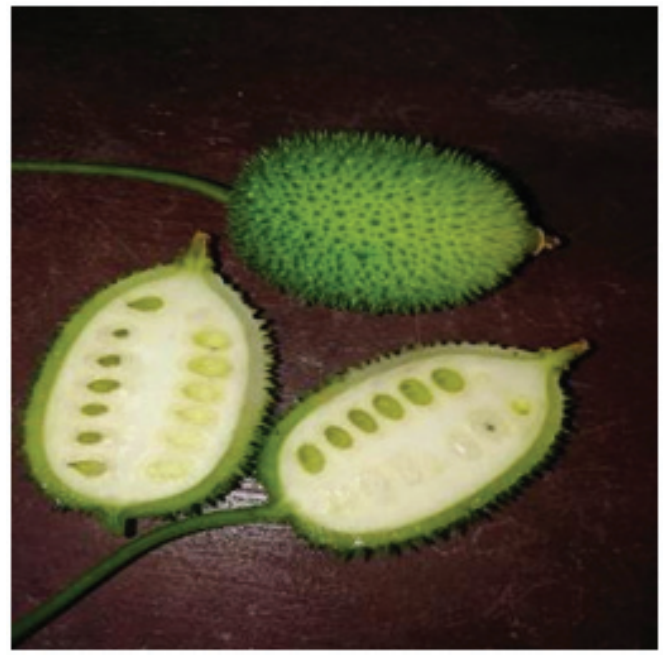

Fig. 3: Longitudinal section of $M$. dioica (axil placentation)

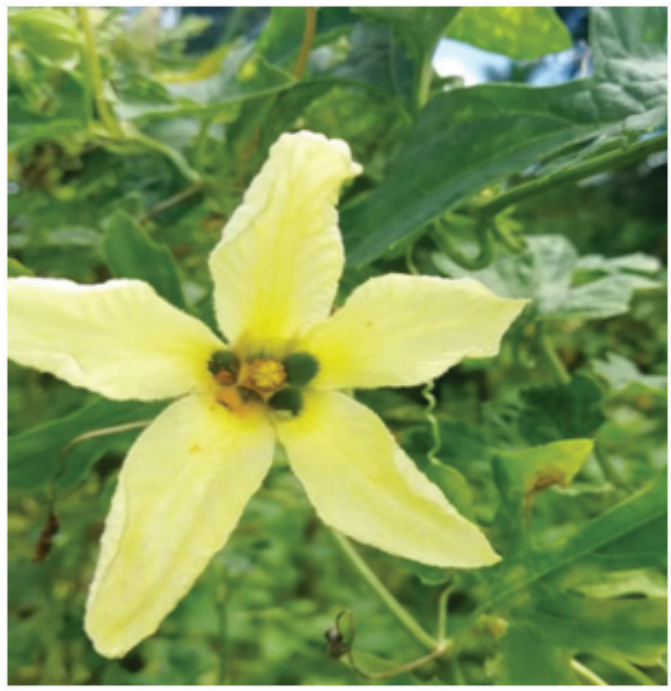

Fig. 5: Morphology of male flower

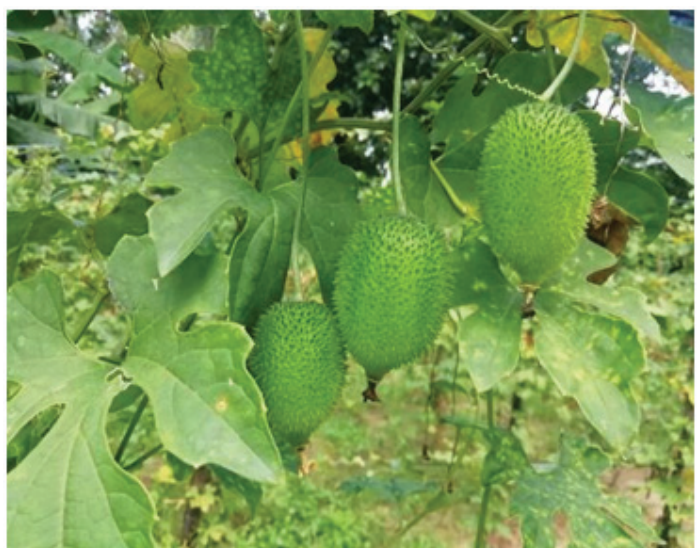

Fig. 2: Morphology of $M$. dioica fruits (short beak with soft spines)

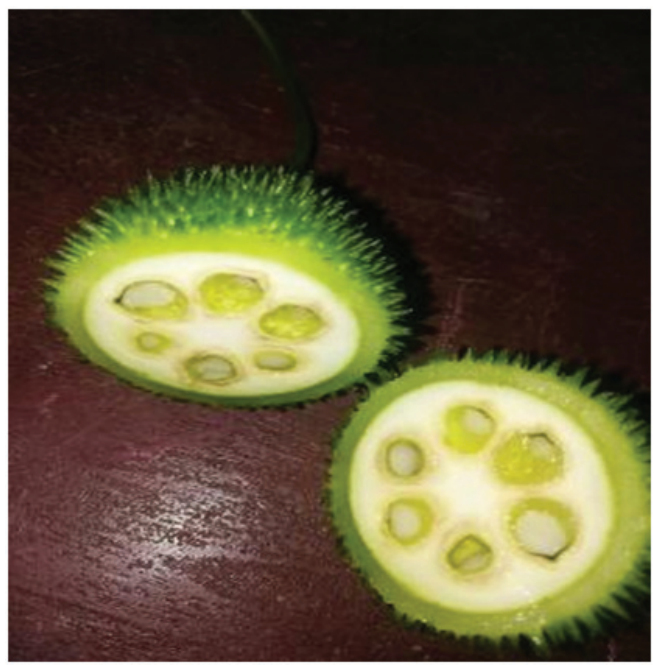

Fig. 4: Cross section of $M$. dioica.

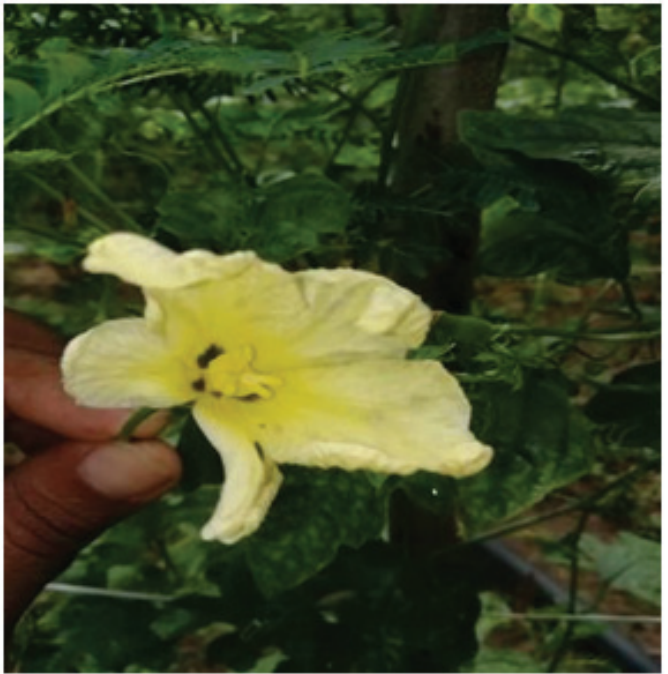

Fig. 6: Morphology of the female flower 
open during the first - second week of September to third week of October (Sandilya el al., 2019). Male flowers are light yellow in colour, long around $2.8 \mathrm{~cm}$. Petals with the shape of oblong or lanceolate and consist of five calyx with linear or lanceolate with five corolla and three stamen. Female flowers consist of small yellow colour bracts having three nectar glands (Bawara et al., 2010). According to Sandilya el al.(2019), male flowers are open around 4.00 am and female flowers around $6.00 \mathrm{am}$. Therefore 5.00-6.00 am is considered as best period for the hand pollination. Fruit sizes are $2-3 \mathrm{~cm}$ in diameter and 2.9 to $5 \mathrm{~g}$ weight. Fruits are short beaked and exocarp is soft, present the spines (Jha et al., 2017). Pods are green during immature and turn to yellow, light green during maturity (Salvi and Katewa, 2015). Ovules are arranged along the free central column of the fruit and seeds are covered with the regulated and hard endocarp (Tissa et al., 2013) because of that, it shows tolerance against the caterpillars;pumping caterpillar, gall fly and root knot nematodes(Anant et al., 2019).
Leaves are simple and broadly ovate with deep lobes in outline, generally length is in between 3.8 to $10 \mathrm{~cm}$ (Bawara et al., 2010). Stem round and branched, furrowed one and elongated tendrils are present (Sandilya et al., 2019).

\section{Utilization of Momordica dioica}

Several studies have been confirmed that M.dioica is a nutritious vegetable and used as folk medicine (Salvi and Katewa, 2015; Nawarathna et al., 2020). According to Bharathi et al. (2010), kernels of the seeds are used for the dying oil for varnish industry. Hexane, an extracted compound, showed the anti-feeding effect of Spodoptera litura. Seed oil of the Momordica shows the insecticidal effect $100 \%$ mortality with the $4 \%$ seed oil concentration. $M$. dioica contains a number of phyto-constituents, bioactive compounds with numerous propertiesare important in the western medicinal treatments and used as insecticidal effects too (Table 1).

Table 1: Phyto-constituents of different plant parts of $M$. dioica and their effect

\begin{tabular}{|c|c|c|}
\hline Plant parts & Extracted compound & Effect of each compound \\
\hline Fruits & $\begin{array}{l}\text { Hexane extract } \\
\text { Methanol extract } \\
\text { n-butanol extract } \\
\text { Hexane and ethyl acetate } \\
\text { extract }\end{array}$ & $\begin{array}{l}\text { Anti-inflammatory property, Neuro-protective ability } \\
\text { Protect the liver cells from damages on hepatocytes, } \\
\text { anticancer effect } \\
\text { Reduction of pancreatic lipase activities } \\
\text { Provide protection against the anti-feeding activity } \\
\text { of cotton leaf worm, Anti-diabetic and antidepressant } \\
\text { properties }\end{array}$ \\
\hline Leaves & $\begin{array}{l}\text { Methanol extract } \\
\text { Aqueous extract }\end{array}$ & $\begin{array}{l}\text { Hepato-protective,Anti-hepatotoxicity effect } \\
\text { Allelopathic activity on seedling growth, seed } \\
\text { germination }\end{array}$ \\
\hline Root & $\begin{array}{l}\text { Alcoholic extraction } \\
\text { Ethanol extraction } \\
\text { Methanol }\end{array}$ & $\begin{array}{l}\text { Inhibit the formation of free oxygen radical } \\
\text { Inhibit the growth, Anti-fertility effect } \\
\text { Anticancer effect }\end{array}$ \\
\hline Seeds & Seed oil & $\begin{array}{l}\text { Provide protectant against Callosobruchus chinensis, } \\
\text { Antiallergic effect }\end{array}$ \\
\hline
\end{tabular}

(Source: Talukdar et al., 2014; Jha et al., 2017).

\section{Nutritional values}

According to the available reports, three triterpenes and two steroids compounds could be isolated from the M. dioica fruit (Jha et al., 2017; Talukdar et al., 2014). Phytochemical studies indicated that spine gourd have high nutritional value which contain proteins, triterpenes and high amount of vitamin $\mathrm{C}$, iodine, alkaloid, flavonoids, glycosides, amino acids and trace of manganese (Talukdar et al., 2014); carotene, thiamine, riboflavin and niacin (Salvi and Katewa, 2015) and good source of chromium and zinc (Talukdar et al., 2014). Results showed that $50 \mathrm{~g}$ of edible fruit contain $42.1 \%$ moisture, $3.35 \mathrm{~g}$ carbohydrate, $1.9 \mathrm{~g}$ protein, $1.56 \mathrm{~g}$ fat, $1.5 \mathrm{~g}$ fibre and $0.5 \mathrm{~g}$ minerals calcium $16.5 \mathrm{mg}$, iron $2.3 \mathrm{mg}$ and phosphorous $4.21 \mathrm{mg}$ (Jha et al., 2017). 


\section{Medicinal value}

Antioxidant Activity: $M$. dioica have compounds with antioxidant property and have the ability inhibit the formation of oxygen derived free radicals and protect the cells (Anant et al.. 2019).

Fruit extracts have diuretic, alexiteric stomachic, laxative, hepatoprotective, and antivenom properties. It is used to cure asthma, leprosy, excessive salivation (Bawara et al., 2010) and to prevent the inflammation caused by lizard, snake bite, fever, mental, digestive disorders and troubles of heart. Because of these properties fruits are used for treating the pimples and acnes on the skin (Talukdar et al., 2014).

Anticancer activity: According to the report of Anjana et al.(2020), root extracts have different constitutions with anti-cancer property. Áspinasterol-3-o-â-D-glucopyranoside is the one of major compound that show effect against the cancer cells (Jha et al., 2017; Talukdar et al., 2014).

Antifertility effect: Talukdar et al.(2014), mentioned that $M$. diocia have effect on antifertility. He concluded that fruit extracts have ability to induces the anti-fertility effects on female rats while have no effect on male rats.

Allelopathic activity: $M$. dioica seed oil has naturally insecticidal properties. By spraying the extracted oil on the cereal grain, it provides antifeed activity against the cereals feed insects (Anjana et al., 2020).

\section{Ayurvedic values}

Ancient peoples used M. dioica as a folk medicine other than the vegetable (Anjana et al., 2020). Spine gourd root juices contain the antidiabetic, anti-inflammatory effect and extract of the spine gourd leaves applying on the head is better treatment for the headache. When applied, root extracts over the whole body provides the superficial effect for high fever. Oral administration of the leaf past is used for many skin diseases as pimples, acnes and softening the skin (Talukdar et al., 2014). M. diocia is the most effective nutrient vegetable for the children, lactating and pregnant mothers because, it creates good strength on the immune system in the body (Salvi and Katewa, 2015), used to treatment the eye diseases and as a medicine for diabetes (Jha et al., 2017).

\section{Cultivation}

It is a worm seasonal crop, successfully cultivated in the subtropical and tropical regions.
Plenty of sunshine and low humidity conditions with well drained sandy loam soil with neutral $\mathrm{pH}$ value (between 5.5- 6.5) provide a comfortable zone for the plant growth. Around $27-33^{\circ} \mathrm{C}$ is ideal condition for the maximum growth and yield of the plant (Ponnusamy and Balusamy, 2019). Before planting, the land should be well ploughing with organic manure or farm yard manure. The plant spacing will be at 1-2 $\mathrm{m}$ between two plants and seeds are sown at a depth of 1-2 cm. Plants are highly susceptible to water logging and also affected by drought condition. Insect and pest damage is correlated with the environment factors. Insect pests population is more during AugustSeptember and make considerable damage to the plants (Anant et al., 2019). Fruit fly (Bactrocera cucurbitae) are the most devastating group of pests that affect on the potential yield of the Marmodica. Red pumpkin beetle, leaf eating caterpillar, cucumber moth and hairy caterpillar are some of threatening insects for the dioica (Anant et al., 2019).

\section{Propagation}

$M$. dioica can be propagated by seeds, cutting (Nawarathna et al., 2020) or tuber (Jha et al., 2017). Seeds have dormancy for 5-6 months. Dipping the seeds in water for a day at the $30^{\circ} \mathrm{C}$ showed better germination (Thiruvengadam et al., 2011). The cutting of terminal vine with 2-3 nodes is the best portion for easily rooting (Ponnusamy et al., 2019). 70-80 days after sowing plants reach commercial maturity (Anjana et al., 2020). Tissue culture is another propagation way that was identified recently. There are four types of explants, $M$. dioica node, shoot tip, leaf and the cotyledon; cotyledons are the best propagating material. MS media with the combination of $0.1 \mathrm{mg} / 1 \mathrm{NAA}$ and $1.0 \mathrm{mg} / 1 \mathrm{BAP}$ shows the best performances for the callus formation. MSHP +Ads+ IBA + Agar are the best combination treatment combination for root development (Deokar et al., 2003). Other than conventional breeding methods, direct organogenesis is the novel method for the propagation of diocia (Thiruvengadam and Chung, 2011).

\section{Conclusion}

Nearly $90 \%$ of global food demand is fulfilled by the few of dominated crops worldwide. Another $10 \%$ is covered by the rest of the crop types, which 
are considered as the underutilized and nonneglected crops. The majority of these underutilized crops have significant nutritional and the health benefits. Also have a long history as its uses in the Ayurvedic industry. Most of these underutilized crops are dominant in the rural agriculture and provide to the rural household income, food and nutritional security. M.dioica is a medicinal and nutritious vegetable with capability to grow in the limited space even as a potted plant with simple potting media.

M. dioica is a kind of wild relative of Momordica plant spp, there are a number of identified poor qualities such as small size fruit, low yield, flowers ratio are not synchronized properly resulting yield of low quality and quantity. Breeders should pay their attention to develop the new dioica spp, by replacing the unwanted wild features. As the fruits are seasonal and limited availability, there is huge potential to prepare the value added and nutritious products.

\section{REFERENCES :}

Anant, P., Painkra, K., Painkra, G., Tiwari, J. and Bhagat, P. 2019. Seasonal incidence and extent of damage by cucurbit fruit Fly, Bactrocera Cucurbitae (Coq.) on spine Gourd (Momordica Dioica Roxb.). Journal of Plant Development Sciences,11( 9): 543546.

Anjana, M., Swathi, V., Ramya Sai, A., Divya, N. and Sunisha, Y. 2020. A Review on Momordica dioica fruits. Journal of Advancements in Plant Science, 3: (1): 1-5.

Bawara, B., Dixit, M., Chauhan, N. S., Dixit, V. K. and Saraf, D.K. 2010. Phyto-pharmacology of Momordica dioica Roxb. ex. Willd: A review. International Journal of Phytomedicine, 2: (1): 1-9.

Bharathi, L.K., Munshi, A.D., Behera, T. K., Joseph John, K., Nath, V. and Bisht, I.S. 2010. Genetic resources of spine gourd (Momordica dioica Roxb. ex Willd.): An underexplored nutritious vegetable from tribal regions of eastern India. Cambridge journal (Plant Genetic Resources: Characterisation and Utilisation) 8:(3): 225-228.

Dahanayake, N. 2015. Some neglected and underutilized fruit crops in Sri Lanka. International Journal of Science and Research Publications, 5: (2):1-7.
Deokar, P.L., Panchabhai, D.M. and Tagade, U.G. 2003. Tissue culture studies in spine gourd (Momordica dioica Roxb.). Annals of plant physiology, 17(1): 64-69.

Hitinayake, H.M.C., Sumanarathne, J.P., Abesekara, W.A.D.S., Madushika, K.G.N., Danushka, W.M. and Sawarnalatha, K.G. 2017. Yield improvement of spine gourd through gynomonoecious hybrid. Annals of Sri Lanka, Department of Agriculture, 19: (2): 71-78.

Jha, D.K., Koneri, R. and Samaddar, S. 2017. Momordica dioica Roxb - A Review. International Journal of Pharmaceutical Sciences Review and Research, 45: (37): 203-209.

Nawarathna, S.L., Subasinghe, S., Vidanapathirana, N. P. and Kumarasinghe, H. K. K. S. 2020. Impact of potting medium and cutting types on rooting and survival performance of male plants of Momordica dioica. Roxb (Thumba Karawila). International Journal of Minor Fruits, Medicinal and Aromatic Plants, 6(2): 72-79.

Ponnusamy, J. and Balusamy, A. 2019. Spine gourd. Kerala Karshakan e-journal 4: (January):45-47.

Salvi, J. and Katewa, S.S. 2015. Nutritional Composition of Momordica dioica fruits: As a wild vegetable. Journal of the food and pharmaceutical sciences, 3: (2):18-22.

Sandilya, V.K., Ram, N., Pradhan, V., Kumar, R. and Tiwari, J.K. 2019. Pollination and fruit setting mechanism in spine gourd (Momordica dioica Roxb). Journal of Pharmacognosy and Phytochemistry, 8: (6): 685-690.

Talukdar, S.N. and Hossain, M.N. 2014. Study of Momordica dioica. Hindawi Publishing Corporation. V, 11.https://www.hindawi.com/ journals/ecam/2014/806082

Thiruvengadam, M. and Chung, I.M. 2011. Establishment of an efficient Agrobacterium tumefaciens-mediated leaf disc transformation of spine gourd (Momordica dioica Roxb. ex Willd). African Journal of Biotechnology,10:(83): 19337-19345.

Tissa, R., Herat, S. Somaratne and P.P.D.C. Perera. 2013. Common vegetables in Sri Lanka. Journal of Chemical Information and Modeling (Vol. 53, pp. 1689-1699). 